\title{
Japanese Fundraising: A Comparative Study of the United States and Japan
}

Received (in revised form): September 17, 2007

\section{Tamaki Onishi}

is a Ph.D. candidate of The Center on Philanthropy at Indiana University. She has an M.A. in Arts Administration from Columbia University and gained fundraising experience at Thirteen/WNET New York. She teaches graduate students fundraising at Aichi Prefectural University of Fine Arts and Music. She has frequently been invited to make presentations in Japan and has appeared in national publications such as Yomiuri Newspaper, in which she also has a regular column. Her current research topics include charitable trusts (for Trust Companies Association of Japan) and financial resources of social entrepreneurs.

\section{Abstract}

The enactment of the Law to Promote Specified Nonprofit Activities in 1998 has resulted not only in a rapid increase in the number of specified nonprofit corporations (NPO corporations) but also in an urgent need for effective fundraising in Japan. Despite Japan's long and rich tradition of philanthropy and a serious need for fundraising, very little research on Japanese fundraising has been available. With original data collected via surveys and interviews from fundraisers in Japan and the United States, this paper analyzes the application of fundraising techniques by Japanese fundraisers and identifies their primary practices. Given the differing views on fundraising between the two countries, which the author ascribes to issues of cross-national comparability, the study investigates fundraising current practices in Japan by using the

\section{Author's Contact Address:}

Tamaki Onishi, The Center on Philanthropy at Indiana University, 550 West North Street, Suite 301, Indianapolis, IN 46202, USA

E-mail: tonishi@iupui.edu
US fundraising model as the baseline. Comparisons of fundraising practices among the Japanese, Japanese Americans, and non-Japanese Americans are also examined to determine whether or not fundraising practices are influenced by cultural and societal factors.

International Journal of Educational Advancement (2007) 7, 205-225. doi:10.1057/palgrave.ijea.2150062

Keywords:

fundraising, Japan, Comparative study

\section{Introduction}

In the last decade, we have witnessed significant changes in worldwide philanthropic profiles. Philanthropy and fundraising are rapidly becoming global practices. Relief efforts for recent disasters, such as the Indian Ocean's tsunami, have often crossed borders and motivated giving from donors whose nationality and backgrounds have been very diverse. At the national and regional levels as well, effective fundraising today 
is a critical function that supports nonprofit work and helps develop a vibrant civil society.

Japan is not an exception. Not only as a result of global pressures but also from an urgent need among local communities to reform and re-legitimate the current status (Osborne, 2003), Japan's nonprofit sector is developing dramatically. The tragic events of the 1995 Hanshin Awaji earthquake demonstrated the significance of the voluntary and nonprofit sector for social welfare and the critical role that civic groups played in compensating for the limitations of government support (Imada, 2003a; Ouchi, 2004). As a result, the Law to Promote Specified Nonprofit Activities (hereafter NPO Law) was enacted in 1998. The NPO law allows citizens to acquire legal status for their voluntary groups without judgment of and control by the government, as long as their activity is dedicated for public benefit. The number of specified nonprofit corporations, grassroots voluntary organizations incorporated under this law (Tokutei Hieiri Katsudo Hojin, hereafter NPO corporations), is rapidly increasing. During the last eight years, 29,934 NPO corporations have been formed and registered (Yamauchi et al., 2007). In 2003, approximately 400 NPO corporations were created monthly, which constituted the fastest growing sector within Japan's nonprofit public-interest world (Matsubara and Todoroki, 2003).

\section{An Increased Need for Fundraising in Japan}

The growing number of NPO corporations has resulted in an increased need for effective fundraising in Japan. To understand why this discussion began fairly recently while nonprofits existed even before the enactment of the NPO Law in 1998, we need to comprehend a confusing array of incorporation categories, since Japan's nonprofit sector has a very complex structure concerning incorporate status ${ }^{1}$ (Amenomori, 1993; Deguchi, 2001; Amemiya, 2002; Yamaoka, 2002; Matsubara and Todoroki, 2003). Among various categories, ${ }^{2}$ there are two distinctive types: ${ }^{3}$ the conventional type called public-interest corporations (Koeki Hojin $)^{4}$ prescribed by the Civil Law of 1897 and the new type of NPO corporations, many of which used to be unincorporated grassroots civic groups. Distinguishing these two types is important in this study. Public-interest corporations, over which the government exercises strict and ongoing control especially in the areas of budget and operations, have no incentives for fundraising (Matsubara and Todoroki, 2003). NPO corporations, on the contrary, must actively raise funds to sustain their operations, as do IRS501(c)(3) in the United States. This study focuses chiefly on the second type, ${ }^{5}$ while not excluding other types as long as they are undertaking fundraising.

Considerable data demonstrate critical demands for fundraising in Japan. A 1999 survey of nonprofit managers conducted by the Tokyo Voluntary Action Center revealed that fundraising was the biggest challenge for 65 percent of the respondents. The Japan Institute for Labour Policy and Training's study (2004) found that NPO corporations most urgently seek those who are good at fundraising. Behind this need lies the 
fact that many NPO corporations are struggling to survive. The Research Institute of Economy, Trade and Industry (hereafter RIETI, 2003) discovered that the average annual revenue of NPO corporations had declined from JPY18.58 million $(\$ 154,800)^{6}$ to JPY15.30 million $(\$ 127,500)$ since the previous survey.

\section{Tradition of Japanese Philanthropy and Fundraising}

Despite such a high demand for fundraising, the author's initial study (Onishi, 2005) found that many interviewees maintained that fundraising rarely exists and will not develop in Japan. Their major explanations are all factors that the United States has, but Japan lacks a culture of giving, tax incentives, the strong tradition of religion and democracy, and wealthy individuals (Matsubara and Todoroki, 2003; Ouchi, 2004).

Giving data confirm weak philanthropy in Japan (Salamon et al., 2003; Yamauchi, 2004; Yamauchi et al., 2007). According to an estimate by The Japanese Nonprofit Almanac (Yamauchi et al., 2007), Japan's private giving totals JPY710 billion ( $\$ 5.92$ billion) in contrast to US giving of \$295.02 billion in 2006 . In the last ten years, the annual average giving per household has remained relatively constant at merely JPY3,277 (\$27.3; Yamauchi et al., 2007), except for the year 1995, when the Kobe earthquake struck.

Although Japanese philanthropy may appear far from generous statistically, many also argue that Japan has a long and rich history of philanthropy and fundraising (Seig and Asaoka, 2002; Imada, 2003a; Aoki,
2004; Katsumata, 2006). Katsumata (2006) and Imada (2003a) disagree with the view that Japan has not fostered private philanthropy since the public depends on the government for social welfare services (London, 1991; Ouchi, 2004).

The source of Japanese charitable organizations can be traced back to Shika-In built by Prince Shotoku during the seventh century (Iamada, 2006). Kanjin, ${ }^{7}$ a Japanese Buddhist model of organized fundraising, dated from the eighth century and developed during the eleventh century (Lohmann, 1995). Kanjin resembles today's capital campaign because it was organized to raise funds for a specific project, such as building a temple, and people were solicited according to their financial capability. ${ }^{8}$ The Edo period (16031867) saw wealthy merchants in Osaka city making contributions to build public facilities and communities. A merchant created Akita Kan'on-ko, a community trust fund, through solicitation with the general public of the Akita region to help the needy regardless of their geographical locations (Katsumata, 2006). ${ }^{9}$ The Meiji period (1868-1912) produced successful industrialists dedicated to philanthropy, such as Eichi Shibusawa. It was during the post Second World War era, when drastic changes were made in the national system and the Constitution, that charitable giving declined (Matsubara and Todoroki, 2003).

Some interviewees mentioned that there seems to be a sign of "rebirth of Japanese philanthropy," which symbolizes a total of over JPY160 billion ( $\$ 1.3$ billion) contributions made to aid Kobe earthquake relief (Pekkanen, 2003). Mr. Yoichiro Abe, 
Assistant Director of the Central Community Chest of Japan, stresses that the Japanese are noticeably improving their giving attitudes. ${ }^{10}$ According to a survey conducted by the Central Community Chest in 2000, the majority of respondents "want to continue the support to some degree" (40.3 percent) and "want to keep the same giving level" (24.8 percent) no matter if the economy declines, whereas only 15.8 percent would "stop the support due to personal financial problems." The same study informs us that the proportion of Japanese individuals making donations is as great as 87 percent of the total studied, although the average gift amount per year/person remains very slim. Mr. Osamu Sato of the Community Care Program shared an account of several members who were disappointed at not having been solicited and asked him to do so in future. ${ }^{11}$ The term charity appears over a range of media and Yahoo.com often hosts charity auctions. Ms. Hideko Katsumata, Managing Director and Executive Secretary of Japan Center for International Exchange, regards the recent record revenue of approximately JPY 1.4 billion ( $\$ 12$ million) raised by Hottokenai Sekai no Mazushisa, Japan's national campaign for the Global Call to Action against Poverty, as a mark of today's growing interest in supporting a cause among Japanese people. ${ }^{12}$

\section{Purpose of the Study}

Such an interest in philanthropy, however, does not necessarily pervade throughout the wide public or even among all nonprofit leaders. During the author's interviews, some even expressed a strong resistance against the idea of advancing fundraising, because fundraising is often regarded as a "forceful act of asking for money in Japan"13 (Central Community Chest, 2003). Their concern is not unreasonable. The term can hold an extremely negative connotation; hence, nonprofit managers should avoid undertaking such practices.

The author ascribes such negative views on fundraising to the issues of cross-national comparability. Unlike the Japanese public perception, scholars and practitioners advancing the fundraising field in the United States define fundraising as practices beyond the mere technical skills of asking for money (Wagner, 2001), let alone forcing people to pay ("fundraising should never be undertaken simply to raise funds" in Rosso, 2003, p. 16). Because trust is the critical foundation in raising funds (Burlingame, 1997; Tempel, 2003), fundraising is the "management of relationships between a charitable organization and its donor publics" (Kelly, 1998, p. 8).

Given the differing views on fundraising between Japan and the United States, it is almost impossible to determine the condition of Japanese fundraising and conclude that it is weaker than the United States, unless both countries' practices are analyzed based on the same criteria. Therefore, the present study investigates fundraising practices in Japan with the US fundraising model serving as the baseline (Wagner, 1997) by gathering original data via surveys and personal interviews with Japanese fundraisers and their American counterparts. Although the number of comparative studies about international fundraising is increasing, few appear to adopt this 
method. The findings aim to identify the primary strategies adopted by Japanese fundraisers, which would then help western fundraisers strategize their fundraising programs with Japanese funders, as well as advance fundraising in Japan. Fundraising practices among the Japanese, Japanese Americans, and non-Japanese Americans are compared to determine whether their practices are influenced by cultural and societal factors.

\section{Factors Affecting Japanese Fundraising}

\section{Overall application of fundraising in Japan}

The first and foremost question is whether fundraising exists in Japan. The Economic Planning Agency's (2000) study on NPO corporations and unincorporated groups suggests that 43.9 percent of incorporated respondents and 79.6 percent of unincorporated respondents are not actively seeking to raise contributions. Matsubara and Todoroki (2003) regard this lack of motivation among NPO corporations as one of the major causes for underdeveloped philanthropy in Japan.

On the other hand, US researchers (Frost and Frost, 1999) identify many fundraising techniques used in Japan, ranging from telethons, child sponsorship, to direct mail and special events, although their study highlights large and western-headquartered nongovernmental organizations (hereafter NGO) and does not reflect the situations of the majority of domestic grassroots nonprofits. While many domestic NPO corporations are suffering from insufficient funds, other organizations such as ASHIAGA are successfully raising funds (Matsubara and Todoroki, 2003). Furthermore, the Central Community Chest (2000) identified that the biggest reason why the Japanese did not donate was because "they were not asked for support" (36 percent). Thus, the author first posits:

Premise 1: Fundraising practices exist in Japan. Yet, practices may be skewed to certain organizations or conditions. Consequently, not all fundraising efforts reach a wide public effectively.

\section{The condition of philanthropic market and cultural factors}

Fundraising is undoubtedly affected by the condition of the philanthropic market. In Japan, the majority (75.4 percent) of philanthropic giving comes from corporations, such as businesses and foundations, while individual giving accounts for only 24.6 percent (2004 data, Yamauchi et al., 2007). The legal treatment of individual giving that allows tax deduction only for a part of the charitable donations for Nintei NPO corporations, which total only 70 (as of July 2007, the website of National Tax Agency), would not support fundraisers' jobs. Koden, a monetary gift given to defray funeral costs, is a common practice among the Japanese (Smith et al., 1999) and some large nonprofits began raising Koden gifts. Yet, there are legal constraints. Mr. Tatsuo Ota, President of The Japan Association of Charitable Organizations, underscores the current limitation of handling bequests and charitable trusts to financial institutions that are primarily motivated by economic goals rather than charitable 
reasons, and this hinders the development of philanthropy. ${ }^{14}$

Philanthropy and fundraising are deeply tied to cultural factors and personal interest. Despite a low degree of religious consciousness among Japanese people, Buddhism and Confucianism have shaped their tradition and cultural values, which, in turn, influence the characteristics of their giving behaviors. A strong sense of duty of exchange etiquettes, respect for elders, and an attitude of group orientation are among the underlying factors affecting their giving decisions. Thus, the Japanese are more likely to support individuals, organizations, or communities they know in person, especially if asked by respected persons or family (Tucker, 1998; Smith et al., 1999; Chao, 2001; Pettey, 2002). The desire for harmony shapes the Japanese tendency to avoid confrontation (Pettey, 2002) and giving decisions. ${ }^{15}$ Thus, the author posits:

Premise 2a: The selection of fundraising techniques is affected by the condition of the philanthropic market. Since the majority of funding comes from corporations and foundations, proposal writing, a technique generally requested by corporations, is a common fundraising tool. Also, techniques to acquire individual donors and cultivate planned gifts may be limited.

Premise 2b: The selection of fundraising techniques is also affected by cultural factors. Common techniques are likely to have a personal touch and avoid a face-to-face conflict between fundraisers and donors.

\section{Human resource and managerial issues}

Imada (2003b) attributes the reasons as to why NPO corporations have difficulties in fundraising to managerial issues, such as the lack of organizational capacity and insufficient human resources. Frost and Frost (1999) also point out that the dedication of trained, full-time fundraising staff is lacking in Japan. Thus, the author posits:

Premise 3: An organization employing a fundraiser is more actively practicing fundraising.

\section{Execution of the fundraising cycle} Conceptual confusion, besides the gross lack of information and misleading data (Salamon and Anheier 1996), is the most serious issue for comparative studies. Definitions of fundraising and charitable giving differ between Japan and the United States. A charitable gift is defined as one-time giving in return for no goods or services (the websites of the Cabinet Office). Because a gift is not made repeatedly, fundraising does not need to manage the donor relationship. Because professional organizations and educational programs of fundraising are lacking in Japan (Frost and Frost, 1999; Onishi, 2004, 2005), very few educational resources are available to inform Japanese fundraisers that fundraising is the cycle of various practices (fundraising cycle). Thus, the next premise is:

Premise 4: The fundraising cycle is not thoroughly executed. Since fundraising does not include maintenance of an ongoing relationship, stewardship is weak. 


\section{Professionalism of Japanese fundraisers}

In 1999, Frost and Frost concluded that fundraising as a profession was unknown in Japan. Almost five years later, the author's interviews discovered a very different outlook. Despite numerous challenges including challenging employment conditions and underdeveloped infrastructures, Japanese fundraisers are highly motivated. Hence, the author posits:

Premise 5: A reason for the difficulty in advancing fundraising is not the lack of motivation of Japanese fundraisers. In fact, their motivation is high and there are signs of growing professionalism among Japanese fundraisers.

\section{Methodology}

The primary data for the present study were gathered from the surveys conducted with fundraisers ${ }^{16}$ in Japan and the United States. ${ }^{17}$ Prior to the surveys, the author consulted with a wide range of interviewees representing major nonprofits, foundations, corporations, central and local governments, academic and research institutions, and media, in order to comprehend the state of Japan's nonprofit sector. This process helped the author design the survey questions in a way that made it easier for Japanese NPO managers to answer.

The first survey was conducted in Japan from October 2004 to December 2004. The survey instrument was constructed and mailed in late October 2004 to the executive directors or fundraisers of 200 nonprofits throughout all 47 prefectures of Japan. 65 organizations responded (yielding a response rate of 32.5 percent). Of all responses, 62 (31 percent) qualified for data analysis. Drawn randomly from the databases of the Japan NPO Center, the Japan NGO Center for International Cooperation (JANIC), the Environmental Restoration and Conservation Agency (ERCA), and the Welfare and Medical Service Agency (WAM), the sample ${ }^{18}$ included various corporations such as NPO corporations, Approved Specified Nonprofit organizations (hereafter Nintei NPO corporations), and unincorporated civic groups. Publicinterest corporations were excluded. The author proportioned the number of organizations sampled from each prefecture by the population. For instance, more organizations were included from the metropolitan areas than the rural areas. The subsectors of the sample organizations include environment, human services, international affairs, and arts and culture. The number of organizations from each subsector was proportioned as well. ${ }^{19}$

In the United States, two different surveys were conducted via the Internet from October 2005 to March $2006^{20}$ : one survey asked 75 JapaneseAmerican fundraisers about their fundraising practices, working conditions, and challenges, and the other asked 202 non-JapaneseAmerican fundraisers, who have reached or are trying to reach Japanese funders, about their experiences with Japanese funders. 35 JapaneseAmerican fundraisers (yielding a response rate of 46.7 percent) and 50 non-Japanese fundraisers (yielding a response rate of 24.8 percent) responded. The sample was drawn from the public directories and 
websites of the Council for Advancement and Support of Education (CASE), educational institutions that have many Japanese students and alumni, Japan-related organizations, and IRC501 (c)(3) organizations located in New York and California, areas that have the biggest Asian American populations according to US Census Annual Estimate (as of July 1, 2004). The donor lists of Japanese corporations and foundations operated in the United States were consulted as well. The subsectors of the sample included higher education, arts and culture, international affairs, and human services.

Cross-national comparative research is also cross-cultural research when it comes to philanthropy. Therefore, anthropological techniques need to be used to investigate the factors affecting philanthropy, the roots of which may be so deeply engrained in the minds of the fundraisers in the study that they may not be conscious of them. Thus, interviews were conducted with Japanese fundraisers at meetings or via phone in 2004 through April 2007. 30 fundraisers of Nintei NPO corporations were selected, because these organizations are dependent on charitable donations. ${ }^{21}$ The interview questions included topics ranging from fundraisers' previous work experiences to their challenges.

According to Professor Naoto Yamauchi of Osaka University, the scholar representing Japan for the Johns Hopkins Comparative Nonprofit Sector Project, there had been no national survey on fundraising in Japan (Onishi, 2005). Also, most of the terms and concepts used for US fundraising are not known. Hence, careful attention was paid to the design and wording of the questionnaires. ${ }^{22}$ For instance, instead of asking Japanese nonprofit managers whether they "are doing fundraising," the author broke down each practice and asked whether they carried it out. Although the US fundraising model was used, unique cultural practices in Japan, such as "via word of month," were incorporated. The questions also needed to be as simple as possible to make the process easier for Japanese fundraisers. Focusing on the main purpose of the study, the surveys intentionally excluded questions related to the revenue raised against the techniques used. The results were, in general, based on the number of respondents who utilized each technique.

\section{Results and Analysis}

\section{Characteristics of organizations and fundraisers}

With respect to incorporate status, NPO corporations belong to the largest group in the sample of the Japan-based survey (34 responses).

The second largest group is composed of unincorporated civic groups (26 responses). There is one Nintei NPO corporation and one "other." Regarding geographical areas, three organizations are located in the Sapporo and Sendai Metropolitan areas, 24 in the Kanto Metropolitan area, four in the Chubu Metropolitan area, five in the Kansai Metropolitan area, and two in the Kyusyu Metropolitan area. 24 respondents are located in other areas. Compared to statistics of the Cabinet Office, this sampling appears to be well proportioned; thus, the data are considered adequate for analysis. The 
primary activities of the organizations ${ }^{23}$ are child welfare (39 organizations), education $^{24}$ (30 organizations), and social and community development (29 organizations).

35 organizations used fundraisers (45.7 percent of the civic groups and 48.6 percent of NPO corporations). The fundraisers' employment status and positions included in-house/fulltime (40 percent), part-time board (28.6 percent), and full-time board (25.7 percent). 71.4 percent of the survey participants had previous work experience (median 5 years and average 5.9 years). 11.4 percent had over ten years of experience prior to the current positions.

Of the respondents of the US-based surveys, the majority of both JapaneseAmerican and non-Japanese-American fundraisers were in-house staff members (96 percent of non-JapaneseAmericans and 85.7 percent of Japanese Americans). Educational organizations are the majority in both groups (29.4 percent of all JapaneseAmerican respondents and 34 percent non-Japanese Americans), followed by health organizations among JapaneseAmerican respondents (17.65 percent) and international affairs among non-Japanese-American fundraisers (24 percent).

Among the Japanese-American fundraisers, the majority are of the third generation (51.5 percent). 12.1 percent identified themselves as the first generation or the fourth generation. There were no secondgeneration Japanese Americans, whereas 24.2 percent of the respondents identified themselves as "other." With respect to the Japanese composition of the donor group, 51.72 percent of Japanese-American fundraisers worked for almost no Japanese donors, whereas 13.79 percent worked for donor groups composed of almost all Japanese donors.

\section{Results of Premise 1: Various fundraising techniques are applied in Japan}

The survey results (Table 1 ) support the author's premise, determining that contrary to critiques' opinions, various fundraising techniques are being used in Japan as are in the United States.

\section{Results of Premise 2: Types of fundraising techniques used by Japanese fundraisers}

A closer look at each technique, however, shows a very different outlook between Japanese and US fundraisers. As the author posits, Japanese fundraisers rely heavily on proposal writing (84.6 percent of all Japanese survey respondents and 97.1 percent of the organizations hiring fundraisers). Most other techniques are utilized only by fewer than one-third of the respondents unless organizations employ fundraisers. This implies that although overall techniques are being applied in Japan, the application of each fundraising tool is skewed.

Results of Premise 2a: A reflection of the current condition of the philanthropic market on the selection of fundraising techniques

A heavy reliance on proposal writing may mirror the current condition of the Japanese philanthropic market, since much of the funding comes from government, foundations, and corporations/corporate foundations that usually request grant proposals. 
Table 1: A comparison of the fundraising techniques used in Japan and the United States

\begin{tabular}{|c|c|c|c|c|}
\hline \multirow{2}{*}{$\begin{array}{l}\text { Fundraising } \\
\text { techniques }\end{array}$} & \multicolumn{2}{|c|}{ Japanese NPOs ${ }^{a}$} & \multicolumn{2}{|l|}{ US NPOs $^{\mathrm{a}}$} \\
\hline & $\begin{array}{l}\text { All Japanese } \\
\text { NPOs }\end{array}$ & $\begin{array}{l}\text { Japanese } \\
\text { NPOs hiring } \\
\text { a fundraiser }\end{array}$ & $\begin{array}{l}\text { Japanese- } \\
\text { American } \\
\text { fundraiser }^{b}\end{array}$ & $\begin{array}{l}\text { Non-Japanese- } \\
\text { American } \\
\text { fundraiser }^{b}\end{array}$ \\
\hline Proposal writing & $84.6 \%$ & $97.1 \%$ & $96.8 \%$ & $93.1 \%$ \\
\hline Via word of mouth & 38.5 & 45.7 & - & - \\
\hline E-philanthropy & 28.7 & 42.9 & 77.4 & 51.0 \\
\hline $\begin{array}{l}\text { Personal face-to-face meeting with a } \\
\text { donor }\end{array}$ & 26.2 & 42.9 & 96.8 & 96.6 \\
\hline Personal phone call solicitation & 26.2 & 37.1 & 87.1 & 93.1 \\
\hline Public service announcement & 26.2 & 37.1 & 41.9 & 41.4 \\
\hline Presentation to a corporate donor & 24.6 & 34.3 & 90.3 & 97.0 \\
\hline Personalized letter & 16.9 & 22.9 & 80.7 & 97.0 \\
\hline Capital campaigns & 15.4 & 22.9 & 64.5 & 75.9 \\
\hline Collection box & 13.8 & 22.9 & 29.0 & 31.0 \\
\hline In-kind donation & 13.8 & 20.0 & 96.8 & 82.8 \\
\hline Special events & 13.8 & 20.0 & 93.6 & 100.0 \\
\hline Impersonal letter/direct mail appeal & 12.3 & 17.1 & 87.1 & 86.2 \\
\hline Cause-related marketing & 7.7 & 14.3 & 67.7 & 51.7 \\
\hline Door-to-door/street solicitation & 6.2 & 11.4 & 3.2 & 3.5 \\
\hline Corporate sponsorship & 3.1 & 5.7 & 90.3 & 100.0 \\
\hline Media advertisement appeal & 2.3 & 2.9 & 32.3 & 20.7 \\
\hline
\end{tabular}

aThe figure indicates the percentage of the survey participants who answered that they have used a technique.

bThe questionnaire for fundraisers in the US asked the frequency ("Often," "Sometimes," "Rarely," and

"Never"), whereas survey participants in Japan were asked "yes" or "no" questions only for the sake of simplicity for Japanese managers who are not familiar with fundraising concepts. The figures of US participants include the responses of "Often," "Sometimes," and "Rarely."

Techniques to expand a donor base, such as direct mail and special events, are not actively used in Japan. Compared to results from JapaneseAmerican respondents (93.6 percent) and non-Japanese Americans (100 percent), only 13.8 percent of Japanese respondents (20 percent with fundraisers) use special events. Impersonal letter/direct mail appeal is also less common (12.3 percent of all Japanese respondents and 17.1 percent with fundraisers). This result may be a response to the recent policy of the Act Concerning Protection of Personal Information, a new national private law that strictly protects consumer privacy in Japan and prohibits any businesses, including nonprofits, from using personal data such as names and addresses without the prior consent of the principals. Consequently, prospect research information, such as WealthID, is not available in Japan. High mailing cost is another issue (about 75 cents per mailing piece/ envelope) and no discount rate is available for nonprofits' bulk mailing (Matsubara and Todoroki, 2003). Under these circumstances, direct mail appeal is becoming more difficult to implement. The relatively active use of E-philanthropy reflects the fact that many nonprofits have set up their 
websites or joined online giving sites. Japanese fundraisers appear much more comfortable and positive in using the Internet for solicitation, since they can avoid face-to-face solicitations with donors.

\section{Results of Premise 2b: Cultural} influences in the selection of fundraising techniques

Major gifts techniques are considered the most effective among US fundraisers (the all-time highest reported success rate is 85.3 percent; see Philanthropic Giving Index [PGI]). Major gifts solicitations, however, such as a face-to-face meeting $(26.2$ percent of all respondents and 42.9 percent with fundraisers), a personal phone call (26.2 and 37.1 percent, respectively), and a personalized letter (16.9 and 22.9 percent, respectively), are not as actively employed in Japan. Most of those who answered that they use the major gifts techniques worked for western-headquartered NGOs so that they are much more familiar with personal solicitation practices.

On the contrary, the results from non-Japanese Americans correspond well with the PGI data overall. Major gifts fundraising is their most common technique, besides corporate sponsorship (100 percent) and special events (100 percent).

However, when compared to results from non-Japanese-Americans, Japanese-American fundraisers appear to be relatively less active in applying major gifts techniques $(87.1$ percent use personal phone calls and 80.7 percent use personalized letters). Furthermore, breaking down their response about face-to-face meeting by frequency confirms that JapaneseAmerican fundraisers use this technique much less frequently (Figure 1). The fact that both groups are working under the same legal and societal systems suggests that the selection of fundraising techniques is affected by cultural factors more than external factors.

In general, major gifts techniques require direct solicitation of prospective donors. This can lead to confrontations and a situation of "losing face," if the negotiations become complicated and prospects reject fundraisers' requests. Some Japanese fundraisers expressed a fear of rejection and concern whether a "direct ask" may cause unease in donors and completely destroy the relationship with them (Onishi, 2005). A fundraiser at Hunger Free World (HFW), a Japan-headquartered NGO known to be one of the most active in terms of fundraising in Japan, said that their donors do not appreciate face-toface solicitation since they are not used to such an approach. Because donors prefer an "impersonal way of making a donation, such as Internet," ${ }^{25}$ HFW's strategy to expand their donor base primarily addresses indirect solicitations. The experiences convince HFW fundraisers that less pressure on donors, especially prospective ones, works much more effectively and ends up motivating them to donate more. This corresponds with the unique attitude of Japanese Americans who "developed at their pace" (Kitano, 1976; see Pettey, 2002, p. 30).

The tendency to avoid direct solicitation is also true among Japanese-American fundraisers. Although a face-to-face meeting is considered the most effective fundraising technique among many 
Japanese-American respondents (45.2 percent), only 32 percent "often" use this, in contrast with as many as 75 percent of non-Japanese Americans who often use it. Newman (2002) points out that "Asian Americans might consider face-to-face meetings rude or inappropriate, as they tend to take fundraising personally and don't want to lose face" (p. 86). ${ }^{26}$

The second most common fundraising tool in Japan turns out to be "via word of mouth" (38.5 percent of all respondents and 45.7 percent of the organizations with fundraisers). Japanese fundraisers appear much more comfortable using an informal technique. Since giving to NPO corporations is still new in Japan, solicitation by unfamiliar organizations may cause grave discomfort to Japanese people; thus a strategy addressing their personal relationships appears to be highly effective. Chao (1999) underscores a similar attitude among Asian Americans: "successful fundraising efforts (with Asian Americans) require a 'personal touch'. The most effective fundraising appeal is the personal 'ask' from a wellrespected friend or family members" (p. 193) since "informal giving practices are common among Asian Americans" (p. 198).

\section{Results of Premise 3: A positive impact made by having a fundraiser on the application of fundraising techniques}

Table 1 proposes that hiring a fundraiser has a positive impact on the application of overall techniques. The major gifts techniques that often demand considerable time and effort are particularly affected. The application of the face-to-face meeting technique increases from 26.2 to 42.9 percent if an organization has a fundraiser.

\section{Results of Premise 4: Implementation of the fundraising cycle}

Neither comprehensive educational programs nor professional associations for fundraising appear to exist in Japan (Frost and Frost, 1999; Onishi, 2005). Without sufficient educational resources, the concept of the fundraising cycle has not been widely introduced, although Japanese fundraisers may have learned it from their own experiences. The author investigated how much the fundraising cycle was implemented, particularly at the marketing/preparation stage and the stewardship stage. To do so, each practice was broken down and asked in a simple manner such as "are you sending an acknowledgement within a week of a gift's arrival?” (for stewardship) and "are you nominating a volunteer to lead a campaign?" (for marketing/preparation).

Execution of the fundraising cycle: At the marketing/preparation stage The data in Table 2 illustrate Japanese nonprofits' weak execution of the fundraising cycle for marketing/ preparation, as compared to JapaneseAmerican fundraisers. Hiring a fundraiser, however, helps more in actively implementing the marketing process. Only 10.7 percent of Japanese nonprofits recruit volunteer leadership. While the figure increases up to 34.3 percent if an organization has a fundraiser, it is still lower than that of Japanese-American respondents (40.0 


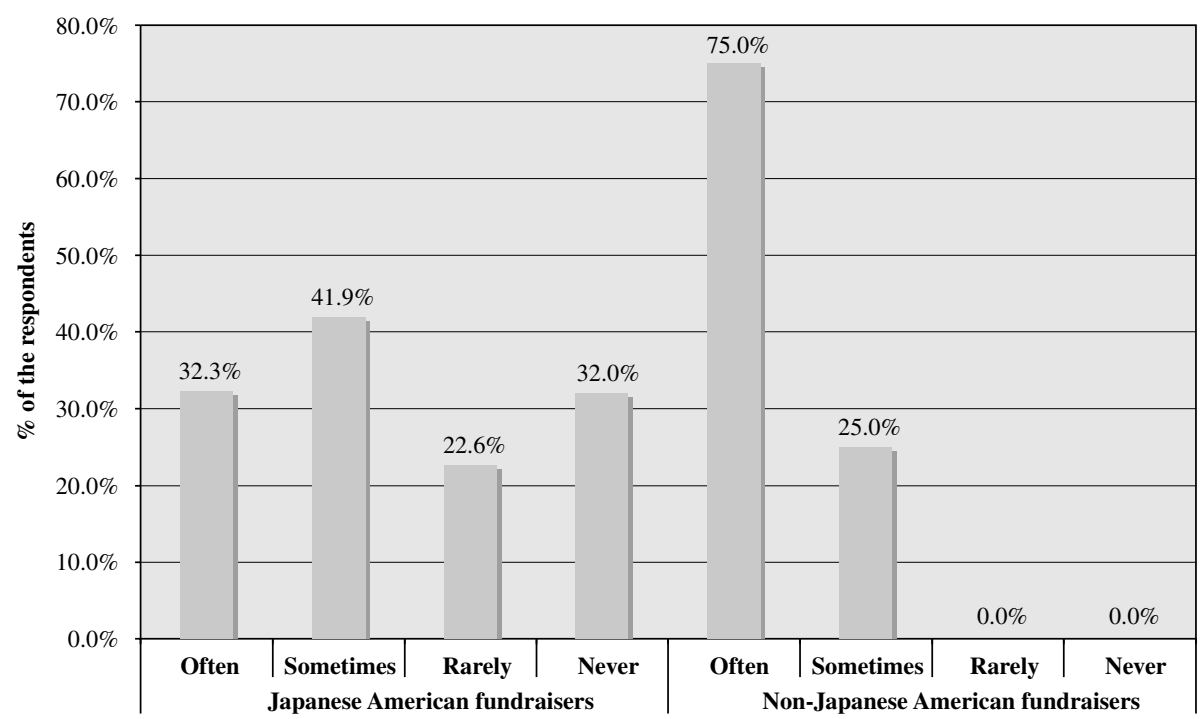

Figure 1: Use of the "Personal Face-to-Face Meeting" technique by Japanese-American and non-Japanese-American fundraisers

percent). Interviews with Japanese fundraisers as well as the survey results suggest that two main reasons exist: (1) volunteer recruitment is not considered important for fundraising and/or (2) Japan's nonprofits do not have enough capacity to recruit and manage volunteers.

Execution of the fundraising cycle: At the stewardship stage

The results in Table 3, too, support the author's premise about weak stewardship in Japan. Stewardship is often not considered as part of fundraising. Only 35.7 percent of Japanese respondents informed donors about the use of their donations. Neither are acknowledgements mailed in a timely fashion $(25$ percent "send it promptly"), nor are they viewed as an effective way of building a strong donor relationship (21.4 percent "send a thank-you letter in addition to a receipt”). 35.7 percent said that they are maintaining accurate information about donors.

\section{Results of Premise 5: An emerging professionalization among Japanese fundraisers}

The survey also found that Japanese nonprofit managers are highly motivated in their fundraising work (Tables 4 and 5). About 80 percent of Japanese respondents answered that their work is valued or highly valued within their organizations. 54.3 percent are greatly satisfied with their work. Their high satisfaction becomes even clearer when compared to Japanese-American fundraisers.

Western researchers suggest that the first sign of emerging professionalism is paid work (Cutlip, 1965). Given this, the data may indicate that professionalism has begun growing among Japanese fundraisers. Many respondents hold paid positions, 
Table 2: Execution of the marketing/preparation

\begin{tabular}{lccc}
\hline & $\begin{array}{l}\text { Japanese NPOs } \\
\text { without a } \\
\text { fundraiser }^{\mathbf{a}}\end{array}$ & $\begin{array}{l}\text { Japanese NPOs } \\
\text { with a } \\
\text { fundraiser }^{\mathbf{a}}\end{array}$ & $\begin{array}{l}\text { Japanese- } \\
\text { American } \\
\text { fundraiser }^{\mathbf{a}}\end{array}$ \\
\hline Conduct marketing research & $10.7 \%$ & $14.3 \%$ & $26.7 \%$ \\
Create a fundraising campaign schedule in advance & 39.3 & 57.1 & 73.3 \\
Nominate a volunteer to lead a fundraising campaign & 14.3 & 34.3 & 40.0 \\
Assemble a volunteer fundraising team & 7.1 & 31.4 & 50.0 \\
Do not prepare for campaign(s) & 14.3 & 2.9 & 20.0 \\
Other & N/A & 5.7 & 13.3 \\
\hline
\end{tabular}

${ }^{a}$ As the questions were designed for multiple answers, the total is not equal to 100 .

Table 3: Execution of the stewardship

\begin{tabular}{lcc}
\hline & $\begin{array}{l}\text { Japanese NPOs } \\
\text { without a } \\
\text { fundraiser }^{\mathbf{a}}\end{array}$ & $\begin{array}{l}\text { Japanese NPOs } \\
\text { with a } \\
\text { fundraiser }^{\mathbf{a}}\end{array}$ \\
\hline Send an acknowledgement promptly & $25.0 \%$ & $37.1 \%$ \\
Send a donor a thank-you letter in addition to a receipt & 21.4 & 60.0 \\
Inform a donor on how the donations have been spent & 35.7 & 65.7 \\
Maintain the accuracy of donor information & 28.6 & 48.6 \\
Make efforts to build a strong relationship with donors & 35.7 & 62.9 \\
Offer various programs to encourage donors to renew & 7.1 & 34.3 \\
\hline
\end{tabular}

${ }^{a}$ As the questions were designed for multiple answers, the total is not equal to 100 .

although most of them were not fulltime fundraisers. However, a large gap exists in the work environment between US and Japanese fundraisers and further investigation is required to draw conclusions. Nonetheless, the author, however, attributes the professionalism of Japanese fundraisers to their commitment to their work, which has dramatically strengthened in the last couple of years.

\section{Conclusions}

Through original data collected via surveys of a comparative study designed with a US model as a baseline, the author found evidence showing a much wider application of various fundraising techniques than presumed by critics. In the following sections, the author will mainly include findings from in-person interviews with Japanese fundraisers and nonprofit leaders in the discussions.

The study's overall findings imply that the underlying reason for the conclusion by Economic Planning Agency (2000) results from the weak organizational capacity and support systems such as insufficient educational opportunities and professional network rather than the lack of fundraisers' motivation. It turns out that many Japanese fundraisers know various techniques to some degree and try to implement them all. They are, 
Table 4: Comparison between Japanese fundraisers and Japanese-American fundraisers: "How do you feel your fundraising work is recognized in your organization?"

\begin{tabular}{lcc}
\hline $\begin{array}{l}\text { Recognition } \\
\text { level }\end{array}$ & $\begin{array}{l}\text { Japanese } \\
\text { fundraiser }\end{array}$ & $\begin{array}{l}\text { Japanese- } \\
\text { American } \\
\text { fundraiser }\end{array}$ \\
\hline Highly valued & $28.6 \%$ & $20.8 \%$ \\
Valued & 51.4 & 54.2 \\
Not valued very much & 2.9 & 12.5 \\
Not valued at all & 2.9 & 4.2 \\
I don't know & 8.6 & 0 \\
No answer & 5.7 & 8.3 \\
\hline
\end{tabular}

Table 5: Comparison between Japanese fundraisers and Japanese-American fundraisers: "Are you satisfied with the current fundraising job?”

\begin{tabular}{lcc}
\hline $\begin{array}{l}\text { Satisfaction } \\
\text { level }\end{array}$ & $\begin{array}{l}\text { Japanese } \\
\text { fundraiser }\end{array}$ & $\begin{array}{l}\text { Japanese- } \\
\text { American } \\
\text { fundraiser }\end{array}$ \\
\hline Greatly satisfied & $54.3 \%$ & $12.5 \%$ \\
Satisfied & 31.4 & 37.5 \\
Not satisfied very much & 5.7 & 33.3 \\
Not satisfied at all & 0 & 8.3 \\
No answer & 8.6 & 8.3 \\
\hline
\end{tabular}

however, often not informed of the importance of teamwork and the whole systematic process of the fundraising cycle. Since most fundraisers have many other responsibilities, they are often overwhelmed by managing fundraising alone. As the survey results prove, if an organization hires somebody who can dedicate considerable time to fundraising, the application of fundraising is significantly improved.

As a result, the stewardship process is left out. Nonetheless, Japanese fundraisers must execute stewardship thoroughly. Chao (1999) underscores that the visible acknowledgement tailored to different levels of giving is highly important to Asian donors. Above all, because the market of Japanese individual donors is currently limited, fostering donors' trust and loyalty to educate them to become long-term supporters is much more important than launching many acquisition campaigns to seek new donors. White Paper by Economic Planning Agency (2000) identified that one of the reasons why the Japanese did not contribute was very little information available about how their donations were used. This implies that stewardship informing donors about the usage of their contributions would urge more individual giving in Japan. Offering more educational programs to enhance the understanding about the principle of fundraising among fundraisers as well as the public is critical to improve their practices.

The study also confirms a distinct sign of the advancement of fundraising in Japan. The last couple of years have witnessed the strengthened commitment of Japanese fundraisers toward their careers. They do not remain pessimistic about the current undesirable social system for nonprofits and charitable giving. This shift appears to positively affect their practices. A head of Bridge Asia Japan, a major NGO that had long been dependent on funding from the government and international organizations such as the United Nations High Commissioner for Refugees, said that she finally acquired a major donor through her almost three years of cultivated efforts. She did not know the donor personally: 
the donor was identified through her research of Nikkei Newspaper. ${ }^{27}$ Today's Japanese fundraisers have also begun to consider their work as a serious career. Mr. Masami Iwafune, a fundraiser of Shanti Volunteer Association (SVA), earned an MBA degree with research focused on marketing applied to his organization when conducting his fieldwork in Thailand. ${ }^{28}$

\section{Suggestions for American Fundraisers}

There are numerous strategies for American fundraisers when they attempt to enter the philanthropic market of Japan. This focuses on fundraising techniques, especially with regard to cultivating new donors.

The present study identifies distinct characteristics of the techniques that Japanese fundraisers prefer to use. Proposal writing possibly continues to be the dominant tool because corporations/foundations have been major donors in Japan and that is what they request.

Japan has a very different tax treatment for charitable giving. Obtaining donor lists is almost impossible and their use can be illegal. The Japanese are not accustomed to being solicited by unfamiliar organizations. All these constraints make individual donor acquisition efforts quite difficult for American fundraisers. Although the present study does not intend to determine the techniques listed at the top of Table 1 as the most effective, we should also know that they are much more familiar techniques for Japanese donors, which would help lessen the pressure of the approach. Given the
Japanese tendency to avoid direct conflict and pressure (Pettey, 2002), comfortable techniques can be considered in approaching prospective donors. Of course, as the relationship develops, some nonprofits use faceto-face solicitations such as in-person meetings and successfully raise a larger amount.

Personal touch and familiarity are essential to attract interest from the Japanese: hence, considerable public relation and media exposure would be necessary, especially if the organization is new to Japan. The Japanese also have the unique preference of subtle nuance in expressions and wordings, which may be hard for non-Japanese individuals to recognize. Compassion is a core element of the Buddhist and Confucian religions and traditional gifts are often made as a gesture of sympathy (Pettey, 2002). Given such cultural values, the Japanese seem more moved by personal stories and gentle expressions. American fundraisers should be able to easily learn from brochures and PR materials of Japanese nonprofits, which are often posted on the website. At the same time, American fundraisers should make all efforts to get to know Japanese people and become part of their community.

Even more patience would be required to cultivate Japanese donors than American donors. They need to confirm a feeling of "sharing" first before being asked. Also, many Japanese donors expect some kind of return from their giving (Pettey, 2002). Hence, preparing goods such as mascots or symbols that are a reminder of the shared experience as a return for giving may be more appealing. The author's survey found 
that this time-consuming process is one of the major challenges frustrating American fundraisers. Yet, this would be a necessary, and eventually rewarding, investment. Considering their strong sense of duty and reciprocity, once they decide to support, Japanese donors would become extremely loyal supporters. Therefore, a distinct strategy to forge a social tie among donors within the community and nurture their sense of reciprocity is required to design effective fundraising strategies.

\section{Acknowledgements}

The author expresses deep appreciation to the Association of Fundraising Professionals (AFP) and The Matsushita International Foundation for their generous financial support, to Dr. Dwight F. Burlingame, Dr. Lilya Wager, and Dr. Cathlene Williams for their profound advice throughout the research, and to Ms. Hideko

Katsumata, Dr. Leslie Lenkowsky, Ms. Jan Masaoka, Ms. Janice Gow Pettey, Dr. Naoto Yamauchi, and Ms. JoAnn Yoshimoto for their invaluable comments. The author is also extremely grateful to many fundraisers and nonprofit leaders in Japan and in the United States who provided much time for interviews and surveys.

\section{Notes}

${ }^{1}$ This typology conflicts with the Structural-Organizational Definition by the Nonprofit Sector long used by Johns Hopkins Comparative Nonprofit Sector Projects (hereafter JHCNSP), which defines nonprofit organizations as "institutionally separate from government" (Anheier and Salamon, 2006).
Even among Japanese scholars, the standard to define nonprofit organizations varies, and there are a significant number of researchers who do not include this conventional group in nonprofit organizations, due to this close relationship with the state. In fact, Amenomori (1993), among the first researchers for JHCNSP, whose research focuses upon the "conventional group," underscores that a large number of Japan's nonprofit organizations, although private and nonprofit in form, may not be qualified as nonprofit organizations under JHCNSP's StructuralOrganizational Definition, mainly because organizations are not totally independent from the state. Yamaoka points out, however, that these organizations can still develop and carry out many unregulated activities like civic movements even under tight control by government, and maintains that they should be considered part of Japan's nonprofit sector (Yamaoka, 2002). ${ }^{2}$ Amenomori (1993) covers broader organizational types ranging from special public corporations (Tokushu Hojin), charitable trusts (Koeki Shintaku), cooperatives (Kyodo Kumiai), children's associations (Kodomokai) to community-based mutual help organizations (Jichikai/Chonaikai).

${ }^{3}$ It should be noted that there are also numerous civic groups that are not legally incorporated, because it used to be very difficult to obtain legal status for nonprofit corporations under the Civil Law. Under the NPO Law, these civic groups began to be incorporated as NPO corporations (Yamaoka, 2002). ${ }^{4}$ Deguchi calls public-interest corporations "institutionalized non-profit organizations" and new NPO corporations "non-institutionalized non-profit organizations" (Deguchi, 2001). The 
conventional public-interest corporations, incorporated under various laws, also include Social Welfare corporations (Shakai Fukushi Hojin), private school corporations (Gakko Hojin), and religious corporations (Shukyo Hojin), (Amemiya, 2002; Yamaoka, 2002). ${ }^{5}$ The present study uses the term of NPO more broadly as an umbrella term referring to both domestic groups and nongovernmental organizations carrying out international work. Unincorporated groups, too, are included in the analysis, since most of them need to raise funds.

${ }^{6} \$ 1$ equal to JPY120.

${ }^{7}$ Despite many similarities between kanjin and western capital campaign fundraising, English-language references to kanjin are extremely rare (Lohmann, 1995).

${ }^{8}$ Soliciting agents of the kanjin campaigns were called hijiri. They were organized into formal groups and chartered by the great Buddhist temples for the purpose of fundraising (Lohmann, 1995).

${ }^{9}$ Examples include Gansuido and Kaitokudo, higher educational institutions established through charitable gifts from merchants in the early 18th century (Imada, 2003b).

${ }^{10} \mathrm{An}$ interview with Mr. Yoichiro Abe, Assistant Director of Department of Planning and Public Relations at Central Community Chest of Japan; see Onishi (2005).

${ }^{11}$ An interview with Mr. Osamu Sato, the founder of Community Care Program; see Onishi (2005).

${ }^{12} \mathrm{An}$ interview with Ms. Hideko Katsumata of Japan Center for International Exchange was conducted on July 25, 2007.

${ }^{13}$ Researchers of this report (Central Community Chest of Japan, 2003) mentioned that people even in the United States do not wish to be solicited by fundraisers.

${ }^{14}$ An interview with Mr. Tatsuo Ota, President of The Japan Association of Charitable Organizations; see Onishi (2005).

${ }^{15}$ An interview with Ms. Hideko Katsumata of Japan Center for International Exchange was conducted on July 25, 2007.

${ }^{16}$ The present study uses fundraisers and NPO managers interchangeably, referring to those who are involved in fundraising practices in Japan, since for most of them, the responsibility is not solely fundraising, and thus they often do not recognize themselves as fundraisers. ${ }^{17}$ The project was carried out under our US-Japan collaborative research system comprising Dr. Burlingame and Dr. Wagner and Japanese research committee members, as well as Tamaki Onishi, the investigator who plans and executes the research and author of the final report. Japanese research committee members include $\mathrm{Mr}$. Yu Inoue at Bunka Hompo, Professor Yoichi Nakamura at Rikkyo University, $\mathrm{Mr}$. Kyoichi Tanaka at Toyota Foundation, and Ms. Machiko Yamane at the NonProfit Organization Support Center for NPO Program Development. The author expresses deep appreciation to Ms. Yamane for her help to conduct a Japan-based survey. The author held a total of four meetings with these members. ${ }^{18}$ The organizations that rely heavily on the other revenue sources, such as government contracts and fee for service, were excluded as well. Representatives from organizations such as JANIC and WAM reviewed our sample to check whether it reflects the national data so that our survey could produce unbiased data. 
${ }^{19}$ For instance, health and welfare organizations share 50 percent out of all nonprofit organizations in Japan; hence, more health and welfare organizations were included in the sample than other types of organizations.

${ }^{20}$ The URL was e-mailed to the identified fundraisers in early October 2005. ${ }^{21}$ The author expresses deep appreciation to Mr. Akira Matsubara and Ms. Ayumi Suzuki at the Coalition for Legislation to Support Citizens' Organizations for their help during the interview processes in Japan.

${ }^{22}$ The author expresses deep appreciation to Professor Naoto Yamauchi at Osaka University and Japanese research committee members for their advice on the design of a Japan-based survey. ${ }^{23} \mathrm{NPO}$ in Japan specify more than one mission-related activity in registrations with the government; thus, there is some overlap of activities among organizations. Hence, the author chose to use the number of organizations instead of percentage.

${ }^{24}$ It should be noted that these organizations are not the same as the US educational institutions such as universities. ${ }^{25}$ An interview with Hunger Free World; see Onishi (2005).

${ }^{26}$ The author's survey, however, found that only 7.14 percent of JapaneseAmerican respondents chose the answer of "a fear of rejection/losing face" and 10.71 percent of "face cultural/language gaps with non-Japanese donors" as the major personal challenge. There appears to be no correlation between the generation, experiences, and a donor profile. This area needs further research possibly by an anthropological method such as in-person interviews.

${ }^{27}$ An interview with Ms. Etsuko Nemoto, President and CEO of Bridge Asia Japan, was conducted on March 16, 2007.
${ }^{28}$ An interview with Mr. Masami Iwafune of SVA was conducted on March 16, 2007.

\section{References}

Amemiya, T. (2002), "Public-interest corporations: Shadan Join and Zaidan Hojin based on the Article 34 of the civil code an corporations based on the special laws", in Gen Watanabe (ed.), The Present State of Nonprofit Sector in Japan, Tokyo, Japan NPO Center, pp. 9-14.

Amenomori, T. (1993), "Defining the nonprofit sector: Japan”, in Lester M. Salamon and Helmut K. Anheier (eds.), Working Papers of the Johns Hopkins Comparative Nonprofit Sector Project, no. 15, Baltimore, The Johns Hopkins University Institute for Policy Studies.

Anheier, H.K. and Salamon, L.M. (2006), “The Nonprofit sector in comparative perspectives In Walter W. Powell and Richard Steinberg (eds.) The Nonprofit Sector: A Research Handbook, New Haven: Yale University Press, pp. 89-114.

Aoki, T. (2004), Nibon-gata kigyo no shakai koken: Shonindo no kokoro wo mitsumeru (Japanese Corporate Philanthropy: In Search of Its Root, Shonindo in the Edo Period), Tokyo, Toho Shobo.

Burlingame, D.F. (ed) (1997), "Preface in Critical Issues in Fundraising, New York, NY, John Wiley \& Sons, Inc, pp. xvii-xxii.

Central Community Chest of Japan (2000), Kyodo Bokin to borantia ni kansuru ishiki tyosa Survey about the Public Opinions on Community Chest and Volunteer Activities), Tokyo, Central Community Chest of Japan.

Central Community Chest of Japan (2003), Nichibeiei minkan zaigen hikaku tyousa kenkyu bokokusyo (A Report on the Comparison Research of the Public Resources of the US, England and Japan), Tokyo, Central Community Chest of Japan.

Chao, J. (1999), “Asian-American philanthropy: Expanding circles of participation", in Cultures of Caring: Philanthropy in Diverse American Communities, Washington, DC, Council on Foundations, pp. 191-253.

Chao, J. (2001), "Asian American philanthropy: Acculturation and charitable vehicles", in Pies C. Rogers (ed.) Philanthropy in Communities of Color: Traditions and Challenges (ARNOVA Occasional Paper Series, 1(1)). Indiana, Association for Research on Nonprofit Organizations and Voluntary Action (ARNOVA).

Cutlip, S.M. (1965), Fundraising in the United States: Its Role in America's philanthropy, New Brunswick, Rutgers University Press. 
Deguchi, M. (2001), “The distinction between institutionalized and noninstitutionalized NPOs: New policy initiatives and nonprofit organizations in Japan”, in Helmut K. Anheier (ed.), Third Sector Policy at the Crossroads: An International Nonprofit Analysis, London, England, Routledge, pp. 153-167.

Economic Planning Agency, Japan (2000), The Annual White Paper on the National Lifestyle 2000, Tokyo, Ministry of Finance Printing Bureau.

Frost, Y.I. and Frost, G.J. (1999), "Japan in Thomas Harris (ed.), International Fundraising for Not-for-Profits: A Country-by-Country Profile, New York, John Wiley \& Sons, Inc., pp. 207-238.

Iamada, M. (2006), Nihon no NPO Shi (A History of NPOs in Japan), Tokyo, Gyosei.

Imada, M. (2003a), "The voluntary response to the Hanshin Awaji earthquake in Stephen P. Osborne (ed.), The Voluntary and Non-Profit Sector in Japan: The Challenge of Change, New York, Routledge Curzon, pp. 49-50.

Imada, M. (2003b), "The philanthropic tradition and fundraising for the voluntary and non-profit sector in Japan in Stephen P. Osborne (ed.), The Voluntary and Non-Profit Sector in Japan: The Challenge of Change, New York, Routledge Curzon, pp. 188-196.

Katsumata, H. (2006), “Japanese philanthropy: Its origins and impact on U.S.-Japan relations in Tadashi Yamamoto, Akira Iriye and Makoto Iokibe (eds.), Philanthropy \& Reconciliation: Rebuilding Postwar U.S.-Japan Relations, Tokyo, Japan Center for International Exchange, pp. 313-344.

Kelly, K.S. (1998), Effective Fundraising Management, Mahwah, NJ, Lawrence Erlbaum Associates.

Kitano, H.H.L. (1976), Japanese Americans: The Evolution of a Subculture, Englewood Cliffs, NJ: Prentice-Hall.

Lohmann, R.A. (1995), "Buddhist commons and the question of a third sector in Asia," Voluntas, 6, 2, pp. 140-158.

London, N.R. (1991), Japanese Corporate Philanthropy, New York, Oxford University Press.

Matsubara, A. and Todoroki, H. (2003), Japan's "Culture of Giving" and Nonprofit Organizations, Tokyo, Japan, Coalition for Legislation to Support Citizens' Organizations (C's).

Newman, D.S. (2002), Opening Doors: Pathways to Diverse Doors, New York, John Wiley \& Sons, Inc.

Onishi, T. (2004), "Roles of Professional Organizations in the Development of US Fundraising -in the light of the History of American Philanthropy Japan NPO Research
Association Annual Conference, Yokohama, Japan, March 19, 2004.

Onishi, T. (2005), Nibon no NPO/NGO ni okeru fundraising no kino to sono hatten strategies (State and Development Strategies for Fundraising by Nonprofit Organizations and Nongovernmental Organizations in Japan), Tokyo, Tokyo Foundation.

Osborne, S.P. (2003), "The voluntary and nonprofit sector in contemporary Japan: Emerging roles and organizational challenges in a changing society in Stephen P. Osborne (ed.), The Voluntary and Non-Profit Sector in Japan: The Challenge of Change, New York, Routledge Curzon, pp. 7-22.

Ouchi, M. (2004), "Charitable Giving in Japan: A Comparative Study of Japan and the United States," Japan NPO Research Association (JANPORA) Nonprofit Review, 4, 1, pp. 39-52.

Pekkanen, R. (2003), “The politic of regulating the non-profit sector in Stephen P. Osborne (ed.), The Voluntary and Non-Profit Sector in Japan: The Challenge of Change, New York, Routledge Curzon, pp. 53-75.

Pettey, J.G. (2002), Cultivating Diversity in Fundraising, New York, John Wiley \& Sons.

Philanthropic Giving Index: Summer 2007, Indianapolis, IN, The Center on Philanthropy at Indiana University.

Research Institute of Economy, Trade and Industry (RIETI) (2003), NPO hojin katsudo jittai tyosa (Study on the Condition and Activity of NPO Corporations), Tokyo, Research Institute of Economy, Trade and Industry.

Rosso, H. (2003), “A Philosophy of Fundraising in Eugene R. Tempel (ed.), Hank Rosso's Achieving Excellence in Fundraising (2nd Edition), San Francisco, CA, Jossey-Bass, pp. 14-20.

Salamon, L.M. and Anheirer, H.K. (1996), The Emerging Nonprofit Sector: An Overview, Manchester, Manchester University Press.

Salamon, L.M., Sokolowski, S.W. and List, R. (2003), Global Civil Society: An Overview, Baltimore, MD, Johns Hopkins University Institute for Policy Studies.

Seig, M.T. and Asaoka, C. (2002), "Omachishitemsu! Case study of the Japanese Nursing Association," The Case International Journal of Educational Advancement, 3, 1, pp. 56-66.

Smith, B., Shue, S., Vest, J.L. and Villarreal, J. (1999), Philanthropy in Communities of Color, Bloomington, IN, Indiana University Press.

Tempel, E.R. (2003), “Contemporary dynamics of philanthropy in Eugene R. Tempel (ed.), Hank Rosso's Achieving Excellence in Fundraising (2nd Edition),, San Francisco, CA, Jossey-Bass, pp. 3-13. 
The Japan Institute for Labour Policy and Training (2004), Rodo seisaku kenkyuu bokokusyo No.12 (Report on the Labor Policy Study No.12), Tokyo, The Japan Institute for Labour Policy and Training.

Tokyo Voluntary Action Center (1999), Shimin katsudo dantai no jittai oyobi nizu chosa (Research on the Condition and Need of Citizens' Nonprofit Organizations, Tokyo, Tokyo Voluntary Action Center.

Tucker, M.E. (1998), “A view of philanthropy in Japan: Confusion ethics and education in Warren F. Ilchman, Stanley N. Katz, \& Edward L Queen II (eds.), Philanthropy in the World's Traditions, Bloomington, IN, Indiana University Press, pp. 169-193.

Wagner, L. (1997), "US models and international dimensions of philanthropic fundraising in Dwight F. Burlingame (ed.), Critical Issues in Fundraising, New York, John Wiley \& Sons, Inc.
Wagner, L. (2001), Career in Fundraising., New York, NY, Johns Wiley \& Sons, Inc.

Yamaoka, Y. (2002), "Introduction in Gen Watanabe eds.. The Present State of Nonprofit Sector in Japan, Tokyo, Japan NPO Center, pp. 4-8.

Yamauchi, N. (2004), Giving and Volunteering in Japan 2004, Osaka, Japan, OSIPP Center for Nonprofit Research \& Information.

Yamauchi, N., Shimizu, H., Sokolowski, S.W. and Salamon, L.M. (1999), "Japan in Lester M. Salamon, Helmut K. Anheier, Regina List \& Stefan Toepler (eds.), Global Civil Society: Dimensions of the Nonprofit Sector, Baltimore, MD, Johns Hopkins Center for Civil Society Studies.

Yamauchi, N., Takafumi, T. and Takayoshi, K. (eds.) (2007), The Japanese Nonprofit Almanac 2007, OSIPP Center for Nonprofit Research \& Information, Osaka, Japan. 